\title{
THE IMPACT OF R1AND R3A GENES ON TUBER RESISTANCE TO LATE BLIGHT OF THE POTATO BREEDING CLONES
}

\author{
Nadezhda Zoteyeva ${ }^{1 \#}$, Ilze Skrabule ${ }^{2}$, leva Mežaka ${ }^{2}$, Daiga Vilcāne ${ }^{2}$, Guna Usele², \\ Nils Rostoks ${ }^{3}$ \\ ${ }^{1}$ Federal Research Center, N. I. Vavilov All-Russian Institute of Plant Genetic Resources, \\ B. Morskaya, 42, 44, St. Petersburg, 190000, RUSSIA \\ E-mail: nzoteyeva@gmail.com \\ ${ }^{2}$ Institute of Agricultural Resources and Economics, Zinātnes 2, Priekuḷi, LATVIA \\ ${ }^{3}$ Faculty of Biology, University of Latvia, Jelgavas 1, Rīga, LATVIA \\ \# Corresponding author
}

Contributed by Ilze Skrabule

\begin{abstract}
Potato breeding clones were evaluated for resistance to late blight (agent Phytophthora infestans) using tuber inoculation tests and for presence of the resistance alleles of R1 and R3a genes in polymerase chain reaction tests. Among clones tested those expressing high, moderate and low resistance were identified. The data were analysed for the impact of R1 and R3a genes on tuber resistance to late blight in tested plant material. In previous evaluations performed on smaller amount of clones the tuber resistance levels significantly depended on presence/absence of the resistance allele of $\mathrm{R} 3 \mathrm{a}$ gene and did not depend on presence of $\mathrm{R} 1$ gene allele. In the current study the statistical analyses did not prove the significant difference in resistance levels depending on presence of the resistance alleles, neither of R1 gene, nor of R3a gene. Tuber resistant clones bearing $\mathrm{R} 3 \mathrm{a}$ gene resistance alleles still noticeably prevailed over the clones bearing the alleles of R1 gene as well as over the clones bearing the no resistance alleles of both genes. In several cases the resistance of clones with detected resistance allele of R1 gene was higher compared to those derived from the same crosses and showing amplification of the allele of R3a gene or those with no resistance alleles. Clones accumulating the resistance alleles of both (R1 and $\mathrm{R} 3 \mathrm{a}$ ) genes expressed high tuber resistance accompanied by necrotic reaction.
\end{abstract}

Key words: potato tubers, Phytophthora infestans, resistance genes.

\section{INTRODUCTION}

The use of molecular markers in potato breeding offers new opportunities for the selection of advanced genotypes. To date, many markers linked to useful traits have been found. More than 90 resistance $(R)$ genes have been identified in plants, using a wide range of methods including map-based cloning, transposon tagging, and similarity-based DNA library screening (Ingvardsen et al., 2008). To date, more than 25 single dominant genes have been localised on the potato map, most of them being resistance genes (Barone, 2004). Since the development of numerous molecular markers for plant genome analysis, the possibility to select the genotype instead of the phenotype has been closely examined, leading to the concept of molecular marker-assisted selection (MAS) (Paterson et al., 1991). New scientific programmes need to develop methodologies to improve resistance level in new potato varieties using the data of genetic background of breeding plant material.
Potato late blight (agent oomycete Phytophthora infestans) is one of the most destructive diseases of potato, which causes yield losses in all regions where potato is growing. The opinion that foliage resistant varieties minimize risk of tuber blight was widely promoted lately. That is why research was focused on leaf resistance evaluation. Chemical protection with contact fungicides decreases but not eliminates the foliage and tuber infection. During the growing season, even weakly blighted foliage leads to a high proportion of infected tubers (Schwinn and Margot, 1991). Genes conferring race-specific resistance determine "vertical" disease resistance in plants. These $R$ genes interact with specific avirulence genes in the pathogen in a gene-for-gene interaction (Flor, 1971). Eleven $R$ genes originating from the wild species Solanum demissum Lindl. have been discovered in the previous century: $R 1, R 2, R 3$, and $R 4$ by Black $e t$ al. (1953); $R 5$ and $R 6$ by Eide et al. (1959); $R 7, R 8$, and $R 9$ by Malcolmson and Black (1966); and RIO and RII by Malcolmson (1969). In evaluation trials performed by 
H. Steward (Steward et al., 2003) the differential genotypes $R 1, R 10$, and $R 11$, as originally defined by Black, were crossed with $R$-gene-free potato cultivars and the progenies divided into two subpopulations comprising those which had inherited the $R$ gene and those which had not. The field resistance levels of the two groups were compared in a field trial in which they were inoculated with an isolate that could overcome the relevant $R$ genes for resistance to $P$. infestans. The $R$-gene-bearing group was significantly ( $p<$ $0.001)$ more resistant than the $R$-gene-free group.

The $R l$ gene is located on chromosome $\mathrm{V}$ on which multiple other disease resistance genes have been mapped. In comparison to the susceptibility allele, the resistance allele at the $R l$ locus represents a large insertion of a functional $R$ gene (Ballvora et al., 2002). Substantial structural variation exists among the three $R l$ haplotypes from the allohexaploid S. demissum (Kuang et al., 2005). The R3a locus is highly frequent in $S$. demissum. The results of study done on $R 10$ and $R 11$ genes using $R$-gene differentials of Black showed that $R 10$ and $R 11$ are allelic versions of genes at the R3 locus on chromosome XI (Bradshaw et al., 2006). Marker conducting linkage with $R 3$ is also to be linked with $R 6$ and $R 7$ alleles. The resistance alleles of these genes mapped to a similar position as the allele of $R 3$ on the chromosome XI (El Kharbotly et al., 1996).

In a previous study the contribution of the resistance alleles of $R 1$ and $R 3 a$ genes to foliar and tuber resistance was studied in 69 and 38 clones, respectively. Foliar resistance was not found to significantly depend on presence of the alleles $R 1$, nor $R 3 a$ genes, while tuber resistance was found to significantly depend on presence of the $R 3 a$ gene resistance allele (Skrabule et al., 2011). To confirm the positive correlation between tuber resistance levels and presence of targeting gene resistance alleles, evaluation was conducted on a considerably larger amount of potato breeding clones. The main goal of our research is to determine the contribution of genes $R l$ and $R 3 a$ to tuber late blight resistance of potato breeding clones.

\section{MATERIALS AND METHODS}

Plant and infection materials. Advanced potato breeding clones (115) were assessed for tuber resistance to late blight in 2011-2012. The isolates of $P$. infestans were sampled from infected potato plants grown in Priekuḷi experimental field of the Institute of Agricultural Resources and Economics. Isolates were sampled from blighted potato leaflets and placed into cut tubers of late blight susceptible variety 'Adretta'. Lesions were sampled randomly from different clones. Grown mycelium was then placed on tuber slices of variety 'Adretta'. For preparation of the inoculum, mycelium was washed from tuber slices with sterile water. After the inoculum concentration was determined, the suspension was maintained at $4{ }^{\circ} \mathrm{C}$ for two hours. The Black's differentials, each containing $R l-R 11$ resistance genes, were used to determine the isolate virulence. Mixtures of local $P$. infestans isolates sampled in 2010, each expressing genes for virulence - 1.2.3.4.(5).6.7.(8).10.11. and 1.3.4.7.8.10.11., were applied in tuber tests.

Molecular screening. Molecular screening for presence of resistance alleles of $R 1$ and $R 3$ genes for resistance to $P$. infestans was performed for 115 clones. Resistance allele of $R 1$ gene (1399 bp) was detected with marker 76-2S according to protocol adopted from Ballvora et al. (2002) using primers $\mathrm{F}$ 5'-CACTCGTGACATATCCTCACTA-3' and R 5'-CAACCCTGGCATGCCACG-3'. Conditions of amplification were the following: initial incubation at $93{ }^{\circ} \mathrm{C}$ for 3 min, followed by 35 cycles of $93{ }^{\circ} \mathrm{C}$ for $30 \mathrm{~s}, 55^{\circ} \mathrm{C}$ for $45 \mathrm{~s}$ and $72{ }^{\circ} \mathrm{C}$ for $90 \mathrm{~s}$, and finishing with an elongation step at $72{ }^{\circ} \mathrm{C}$ for $5 \mathrm{~min}$. Resistance allele of $R 3$ (981 bp) was detected with marker RT-R3a_L01 following protocol adapted from Huang et al. (2005) using primers F 5'ATCGTTGTCATGCTATGAGATTGTT-3' and R 5'CTTCAAGGTAGTGGGCAGTATGCTT-3'. Reaction was amplified under the following conditions: initial incubation at $93{ }^{\circ} \mathrm{C}$ for $3 \mathrm{~min}$, followed by 35 cycles of $94{ }^{\circ} \mathrm{C}$ for $30 \mathrm{~s}, 64{ }^{\circ} \mathrm{C}$ for $30 \mathrm{~s}$ and $72{ }^{\circ} \mathrm{C}$ for $90 \mathrm{~s}$, and finally an elongation step at $72{ }^{\circ} \mathrm{C}$ for $5 \mathrm{~min}$.

Tuber inoculation tests. The tuber resistance assay was developed based on the method described by Zoteyeva and Zimnoch-Guzowska (2004). Inoculation of tubers was performed two - three months after harvesting. Four tubers of each clone were inoculated. Tubers of similar size were taken from cold storage and washed in tap water. Cut tuber surfaces of $7 \mathrm{~mm}$ diameter were inoculated with a $20 \mu \mathrm{l}$ drop of inoculum. Concentration of the inoculum comprised 15000 zoospores per ml. Tubers were incubated in plastic boxes closed with glass, with $100 \%$ relative humidity, in the dark at $17{ }^{\circ} \mathrm{C}$. The resistance was estimated at the $14^{\text {th }}$ day after inoculation. The resistance grade scale 1-9 (where 9 is the most resistant) rating lesion sizes was used for estimation of symptoms. Clones scored with grades from 5.6 to 9.0 were classified as resistant $(\mathrm{R})$, with grades from 5.0 to 5.5 as moderately resistant (MR) and with grades from 1 to 4.9 as susceptible (S). Tubers of varieties 'Adretta' and 'Madara' which were found to be strongly infected on the $6^{\text {th }}$ day after inoculation in 2010 tuber tests performed in PPBI were used as the susceptible controls.

Statistical analyses. Statistical analyses were performed using statistical software MINITAB 15 . To determine the effect of race specific genes $R l$ and $R 3$ on tuber resistance to late blight, comparison of the number of clones with amplified resistance alleles of genes $R l$ or $R 3 a$ and the number of clones without these alleles, in relation to resistance levels, was performed, consistently grouped using Tukey Method with $95 \%$ Simultaneous Confidence Intervals.

\section{RESULTS}

Among 115 clones tested in polymerase chain reaction tests, the numbers of those with presence of resistance alleles of genes $R I$ and $R 3 a$ were the following: 2 with resistance alleles of the both genes $(R l, R 3 a), 8$ with amplification of re- 
sistance allele for $R l$ gene and 29 with amplification of resistance allele of $R 3 a$ gene. In 76 clones resistance alleles of genes $R I$ and $R 3 a$ were not detected. The tuber resistance reaction of two susceptible controls indicated sufficient infection pressure in tests performed.

A group of clones with detected resistance allele of $R 1$ gene comprised 3 resistant clones (37.5\%), a group with detected resistance allele of $R 3 a$ comprised 12 resistant clones $(41.4 \%)$, and a group of clones without amplified fragments of the both gene alleles comprised 26 resistant clones $(34.2 \%)$. In this evaluation there were two clones with resistance alleles of both genes Rlor $R 3 a$ amplified. The mean resistance grade (7.4) of these clones exceeded the average resistance grades of groups of clones with the resistance alleles of single genes $(R I$ or $R 3 a)$, as well as of those that amplified none of the resistance alleles (Table 1$)$. The average resistance grades within the groups with detected resistance alleles of $R l$ or $R 3 a$ genes and within the group that was alleles free were, respectively, 5.6, 5.6, and 5.5. The results showed very low variability for tuber resistance among these groups of clones due to very close values of the resistance grades of each (Table 1).

Regardless the very close average resistance values found in each group the proportions between resistant and susceptible clones differed. The share of resistant clones was evidently larger in the group bearing an allele of $R 3 a$ gene. Among 29 clones from this group only two were found susceptible, 18 were found moderately resistant, and 9 were resistant. However, the statistical analyses using a confidence level of $95.0 \%$ did not show a significant difference in resistance levels between clones bearing $R 3 a$ gene resistance alleles and the groups of clones bearing the resistance alleles of $R 1$ gene or with any gene alleles amplified $(p<0.5)$. Statistical analyses did not find a significant difference in tuber resistance of clones with alleles of gene $R l(p>0.5)$ and with the group of clones without both gene resistance alleles.

To determine the effect of $R 3 a$ gene for tuber resistance, data on clones derived from the fourteen cross combinations were compared (Table 2). Comparison of the resistance of

$$
\text { Table } 1
$$

DISTRIBUTION OF TUBER RESISTANCE TO PHYTOPHTHORA INFESTANS IN GROUPS OF CLONES WITH PRESENCE/ABSENCE OF RESISTANCE ALLELES OF GENE Rl OR R3a

\begin{tabular}{l|c|c|c}
\hline $\begin{array}{c}\text { Groups of clones with } \\
\text { presence/absence of the } \\
\text { resistance alleles of genes } \\
R 1 \text { and } R 3 a\end{array}$ & $\begin{array}{c}\text { Number of } \\
\text { clones }\end{array}$ & \multicolumn{2}{|c}{$\begin{array}{c}\text { Resistance rating, } \\
\text { (grade scale 1-9) }\end{array}$} \\
\cline { 3 - 4 } & & $\begin{array}{c}\text { infected lesion } \\
\text { size, average } \\
\text { grade }\end{array}$ & $\begin{array}{c}\text { grade ranges } \\
\text { (min-max) }\end{array}$ \\
\hline$R 1, R 3 a$ & 2 & 7.4 & $6.7-8.0$ \\
$R 1$ & 8 & 5.6 & $4.8-6.7$ \\
$R 3 a$ & 29 & 5.6 & $4.0-6.7$ \\
Neither $R 1$ nor $R 3 a$ & 76 & 5.5 & $3.7-7.0$ \\
Susceptible controls: & & & \\
var. Adretta & & 3.6 & \\
var. Madara & & 3.8 &
\end{tabular}

clones with or without $R 3$ gene resistance allele showed the same resistance levels of clones derived from crosses: 'Goya' $\times$ 'Pepo', 'Impala' $\times$ 'Barbara', 'Quarta' × 'Delphin', 'Quarta' $\times$ 'Monta', 'Rosara' $\times$ 'Barbara' offspring (Table 2). Regarding resistance score grades of the clones derived from the other cross combinations the resistance was slightly higher of those with detected resistance allele of $R 3 a$ gene: 'Kolibri' $\times$ A 99437-1 (5.0 versus 4.5), 'Matilda' $\times$ 'Kolibri' (6.2 versus 5.7), 'Quarta' $\times$ 'Barbara' (5.7 versus 5.3), 'Zarevo' $\times$ 'Laura' (mean grades 5.8 versus 5.1). Among eight clones of cross 'Zarevo' $\times$ 'Laura', six showed $R 3 a$ gene resistance allele amplification. Five of them were found as moderately resistant (grades from 5.3 to 6.0 ) and one comprising both gene ( $R I$ and $R 3 \mathrm{a}$ ) alleles expressed a high level of resistance and scored with grade 8.0. One clone without $R I$ and $R 3 a$ genes resistance alleles was susceptible (grade 3.8). Some effect of gene $R l$ in tuber resistance could be assumed regarding the highest resistance (grade 8.0 with necrotic response) of 'Zarevo' $\times$ 'Laura' offspring expressed due to additive effect of both $R l$ and $R 3 a$ genes in clone 19646.2 (Fig. 1). The same reaction and high tuber resistance was shown by clone 19627.26 ('Zarevo' $\times$ 'Raja') with resistance alleles of both genes $(R I$ and $R 3 a$ ) amplified (data is not shown in table). The minimal score grade was evidently higher in group of clones with $R l$ gene resistance allele (4.8) in comparison to 4.0

Table 2

TUBER RESISTANCE OF THE POTATO BREEDING CLONES DERIVED FROM THE SAME CROSS COMBINATIONS WITH/WITHOUT THE AMPLIFICATION OF THE RESISTACE ALLELES OF GENES RI OR R3A

\begin{tabular}{|c|c|c|c|c|c|}
\hline \multirow[t]{2}{*}{$\begin{array}{l}\text { Cross } \\
\text { combinations }\end{array}$} & \multirow[t]{2}{*}{$\begin{array}{c}\text { Number } \\
\text { of tested } \\
\text { clones }\end{array}$} & \multicolumn{4}{|c|}{$\begin{array}{c}\text { Resistance rating of clones with }(+) \text { and } \\
\text { without }(-) \text { resistance allele of gene } R 3 a \\
\text { detected, grade scale } 1-9\end{array}$} \\
\hline & & \multicolumn{2}{|c|}{ - } & \multicolumn{2}{|c|}{+} \\
\hline Impala $\times$ Barbara & 2 & 6.3 & $\mathrm{R}^{1}$ & 6.3 & $\mathrm{R}$ \\
\hline Goya $\times$ Pepo & 2 & 5.0 & $\mathrm{MR}^{2}$ & 5.0 & MR \\
\hline Ausonia $\times 17770.6$ & 2 & 5.7 & MR & 6.2 & $\mathrm{R}$ \\
\hline Kolibri × A 99437-1 & 2 & 4.5 & $S^{3}$ & 5.0 & MR \\
\hline Matilda $\times$ Kolibri & 2 & 5.7 & MR & 6.2 & $\mathrm{R}$ \\
\hline Quarta $\times$ Barbara & 2 & 5.3 & MR & 5.7 & MR \\
\hline Quarta $\times$ Delphin & 2 & 6.3 & $\mathrm{R}$ & 6.3 & $\mathrm{R}$ \\
\hline Quarta $\times$ Monta & 2 & 6.2 & $\mathrm{R}$ & 6.3 & $\mathrm{R}$ \\
\hline Rosara $\times$ Monta & 2 & 6.7 & $\mathrm{R}$ & 6.0 & $\mathrm{R}$ \\
\hline Rosara $\times$ Barbara & 2 & 6.0 & $\mathrm{R}$ & 6.0 & $\mathrm{R}$ \\
\hline Zarevo $\times$ Laura & 10 & $6.3 ; 3.8$ & $\mathrm{R}, \mathrm{S}$ & $\begin{array}{c}8.0 * ; 6.0 \\
5.0 ; 5.8 \\
5.7 ; 5.3\end{array}$ & $2 \mathrm{R}, 4 \mathrm{MR}$ \\
\hline Zarevo $\times$ Folva & 4 & $\begin{array}{c}6.0^{*} ; 4.5 \\
\quad 4.0\end{array}$ & $\mathrm{R}, 2 \mathrm{~S}$ & 5.0 & MR \\
\hline $\begin{array}{l}{[(\text { Zarevo } \times \text { Gauja }) \times} \\
\text { Sož }] \times \text { Kuras }\end{array}$ & 2 & 4.5 & $S$ & 5.0 & MR \\
\hline $\begin{array}{l}(\text { Bereginja } \times \text { Zarevo }) \\
\times \text { Folva }\end{array}$ & 2 & $6.0^{*}$ & $\mathrm{R}$ & 5.0 & MR \\
\hline
\end{tabular}

$\mathrm{R}$, resistant (score grades from 6.1 to 9.0); MR, moderately resistant (score grades from 5.0 to 6.0 ); $\mathrm{S}$, susceptible (score grades from 1 to 4.9 ).

*) - clones with amplification of the resistance allele of gene $R 1$ 

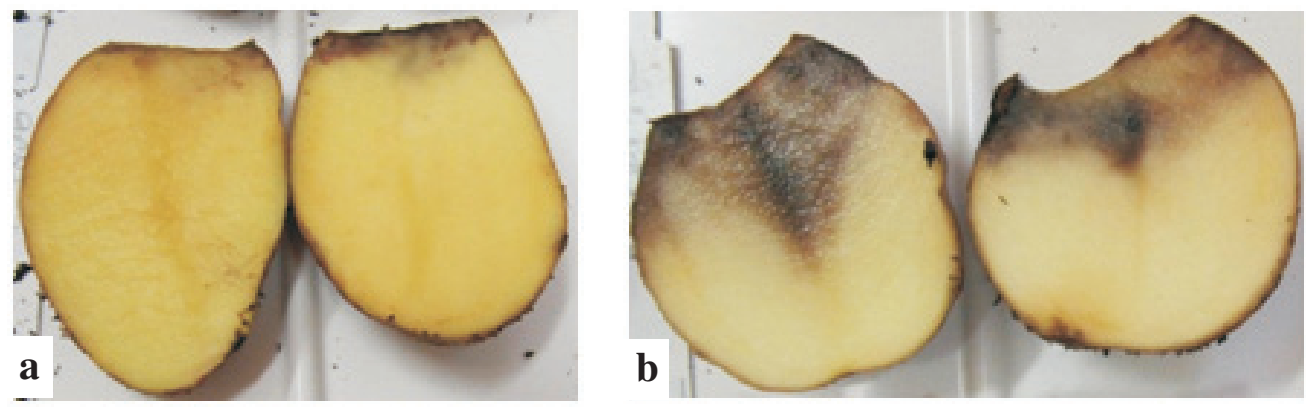

Fig. 1. a, necrotic response to inoculation with Phytophthora infestans in tubers of breeding clone 19646.2 on the $6^{\text {th }}$ day after inoculation; b, infected tubers of the susceptible control (var. 'Adretta') on the $6^{\text {th }}$ day after inoculation.

and 3.8 score grades in groups of clones with $R 3 a$ allele (4.0) and without both gene resistance alleles (3.8) (Table $1)$.

Comparison of the resistance levels of clones derived from the same crosses showed in some cases the prevalence on resistance of clones with $R l$ gene resistance allele detected. One of two clones derived from the cross ('Bereginja' $\times$ ' $\mathrm{Z}$ arevo') $\times$ 'Folva' bearing the allele of $R l$ gene was scored with a higher resistance grade (6.0) than for the other bearing $R 3 a$ gene resistance allele (grade 5.0). Among four offspring derived from cross 'Zarevo' $\times$ 'Folva' the resistance alleles of genes $R I$ or $R 3 a$ were detected in two. Clone with detected $R l$ gene allele also prevailed by the clone bearing $R 3 a$ gene allele (Table 2). Two clones lacking both genes $(R 1$ or $R 3 a$ ) resistance alleles were found to be susceptible (grades 4.0, 4.5).

\section{DISCUSSION}

It has been widely implied that partial resistance is different from the resistance caused by the major $R$ genes, but recent studies indicate that $R$ genes do confer partial resistance against the late blight pathogen (Vleeshouwers et al., 2011). In our current and previous research (Zoteyeva et al., 2014) we focused on two $R$ genes $(R l$ and $R 3 a$ ) for resistance to late blight derived from $S$. demissum Lindl. Data obtained in many studies on phenotypic structure of European populations of $P$. infestans showed that the most common virulence genes are 1. and 3. (Andrivon et al., 1994; Lebecka et al., 2007, Lehtinen et al., 2008, Runno-Paurson et al., 2009; Zoteyeva and Patrikeeva, 2010).

Due to common occurrence of $P$. infestans virulence factors 1. and 3., the effect of use of plant material bearing the resistance alleles of both $R 1$ and $R 3 a$ genes could be accumulated in potato breeding. Past an inoculation with $P$. infestans such clones followed by localized necrosis are typical for a hypersensitive response (Fig. 1). Obviously, this resistance was caused by additive action of both genes, as described previously (Umaerus and Umaerus, 1994) indicating increased tuber resistance due to presence of $R$ genes in potato plants. Such clones can contribute resistance in developed potato varieties. In this study many of tested breeding clones of group in which neither resistance alleles of $R I$ nor $R 3 a$ genes were detected, showed a high level of tuber resistance. Evidently, the resistance found in such clones is imparted by other major genes or quantitative trait loci (QTL).

Many varieties used as parents in the breeding programme of the Institute of Agricultural Resources and Economics (former State Priekuḷi Plant Breeding Institute) were introduced from Europe (including ex-Soviet Union) and North America. The source of tuber late blight resistance found in some breeding clones was due to parental varieties containing resistance genes, probably derived from S. demissum (Skrabule et al., 2011).

Among offspring of the variety 'Zarevo', there were resistant clones lacking $R 1$ and $R 3 a$ resistance alleles amplified (data is not shown in table). Obviously, their resistance is conditioned by a gene other than $R 1$ or $R 3 a$ genes derived from the pedigrees of one of the parents. It might to be assumed that in the genetic background of variety 'Zarevo', which is an interspecific hybrid (Solanum tuberosum L., S. demissum, $S$. andigenum Juz. et Buk), there are other genes for late blight resistance beside $R 1$ or $R 3 a$. Regarding the phylogenic relationship, the offspring of $S$. demissum could confer genes for resistance found in S. bulbocastanum Dun. (Naess et al., 2000; van der Vossen et al., 2005) or newly identified $P$. infestans resistance genes originating from $S$. verrucosum Schlechtd. and S. schenckii Bitt. (Jacobs et al., 2010) belonging to the same taxonomic series as $S$. demissum. The primers specific to $S$. bulbocatanum genes for resistance to late blight were amplified also in the DNA from S. demissum (Balazs et al., 2011). Some potato varieties are progenies of interspecific hybrids. Resistance of breeding clones derived from such varieties could not be conferred by $R I$ or $R 3 a$ genes but might be determined by other genes or QTL for late blight resistance.

Results of this study showed that among the tested clones several resistant clones showed amplification of a specific fragment indicating the presence of the resistance allele of gene $R 3 a$. The resistance alleles of genes $R I$ and $R 3 a$ were frequently amplified in progenies of variety 'Zarevo'. Some clones with resistance alleles of both genes ( $R l$ and $R 3 \mathrm{a}$ ) showed a statistically non-significant trend to express high levels of tuber resistance to late blight accompanied by the necrotic reaction or so-called hypersensitive response (HR). The $R$-genes encode the specific receptors that initiate the signal transduction pathways and involve the HR (Hammond-Kosack and Jones 1997). Plant cell death prevents the further growth of the pathogen, resulting in resistance. 
In order to obtain clear results, the number of clones with both resistance genes tested should be increased. Comparison of the resistance levels of the clones derived from the same cross combinations in some cases showed higher resistance of clones with detected resistance allele of gene $R l$. This suggests the impact of the both genes on tuber resistance to $P$. infestans of the potato clones evaluated.

Tuber resistant clones in which resistance alleles neither of $R 1$ nor $R 3$ a genes were amplified will be screened in the next study using markers for other genes or QTL conferring late blight resistance. The large share of clones conferring resistance associated with $R 1$ or $R 3 a$ genes resistance alleles and high tuber resistance associated with both $(R l$ and $R 3)$ genes are perspective basic material to create $R l$ or $R 3 a$ and $R l, R 3 a$ gene-bearing potato populations.

\section{ACKNOWLEDGMENTS}

This study was co-supported by European Social Fund project: 2009/0218/1DP/1.1.1.2.0/09/APIA/VIAA/099

\section{REFERENCES}

Andrivon, D. (1994). Races of Phytophthora infestans in France, 1991-1993. Potato Res., 37, 279-286.

Balazs, E., Botez, C., Taoutaou, A. (2011). Preliminary results regarding presence of $R B$ genes homologues from Solanum bulbocastanumin some Solanum species. Bull. UASVM Agr. (Bulletin of University of Agricultural Sciences and Veterinary Medicine), 68 (1), 36-41.

Ballvora, A., Ercolano, M. R., Wei, J., Meksem, K., Bormann, C. A., Oberhagemann, P., Salamini, F., Gebhardt, C. (2004). The $R 1$ gene for potato resistance to late blight (Phytophthora infestans) belongs to the leucine zipper/NBS/LRR class of plant resistance genes. Plant J., 30, 361-371.

Barone, A. (2004). Molecular marker-assisted selection for potato breeding. Amer. Potato J., 81, 111-117.

Black, W., Mastenbroek, C., Mills, W. R., Peterson, L. C. (1953). A proposal for an international nomenclature of races of Phytophthora infestans and of genes controlling immunity in Solanum demissum derivatives. Euphytica, 2, 173-179.

Bradshaw, J. E., Bryan, G. J., Lees, A. K., McLean, K., Solomon-Blackburn, S. R.M. (2006). Mapping the R10 and R11genes for resistance to late blight (Phytophthora infestans) present in the potato (Solanum tuberosum) $R$-gene differentials of Black. Theor. Appl. Genet., 112, 744-751.

Eide, C. J., Bonde, R., Gallegly, M. E., Graham, K., Mills, W. R., Niederhauser, J., Wallin, J. R. (1959). Report of the late blight investigations committee. Amer. Potato J., 36, 421-423.

El Kharbotly, A., Palomino Sanchez, C., Salamini, F., Jacobsen, E., Gebhardt, C. (1996). $R 6$ and $R 7$ alleles of potato conferring race-specific resistance to Phytophthora infestans (Mont.) de Bary identified genetic loci clustering with the $R 3$ locus on chromosome XI. Theor. Appl. Genet., 92, 880-884.

Flor, H. H. (1971). Current status of the gene-for-gene concept. Annu. Rev. Phytopathol., 9, 275-296.

Hammond-Kosack, K. E., Jones, J. D. G. (1997). Plant disease resistance genes. Annu. Rev. Plant Physiol. Mol. Biol., 48, 575-607.

Huang S., van der Vossen, E. A. G., Kuang H., Vleeshouwers, V. G. A. A., Zhang, N., Borm, T. J. A., van Eck, H. J., Baker, B., Jacobsen, E., Visser, R. G. F. (2005). Comparative genomics enabled the isolation of the $R 3 a$ late blight resistance gene in potato. Plant J., 42, 251-261.
Jacobs, M. M. J., Vosman, B., Vleeshouwers, V. G. A. A., Visser, R. G. F., Henken, B., van den Berg, R. G. (2010). A novel approach to locate Phytophthora infestansresistance genes on the potato genetic map. Theor. Appl. Genet., 120, 785-796.

Ingvardsen, C. R., Schejbel, B., Lübberstedt, T. (2008). Functional markers for resistance breeding. In: Lüttge, U., Beyschlag, W., Murata, J. (eds.). Progr. Bot., 69, 61-87.

Kuang, H., Wei, F., Marano, M. R.,Wirtz, U., Wang, X., Liu, J., Shum, W. P., Zaborsky, J., Tallon, L. J., Rensink, W., Lobst, S., Zhang, P., Tornqvist, C. E., Tek, A., Bamberg, J., Helgeson, J., Fry, W., You, F., Luo, M. C., Jiang, J., Robin Buell, C., Baker, B. (2005). The R1 resistance gene cluster contains three groups of independently evolving, type I $R I$ homologues and shows substantial structural variation among haplotypes of Solanum demissum. Plant J., 44, 37-51.

Lebecka, R., Sliwka, J., Sobkowiak, S., Zimnoch-Guzowska, E. (2007). Phytophthora infestans population in Poland. In: Proceedings of the 10th Workshop European Network for Development of an Integrated Control Strategy of Potato Late Blight, 2nd-5th May, Bologna, pp. 155-159.

Lehtinen, A., Hannukkala, A., Andersson, B., Hermansen, A., Le, V. H., Nærstad, R., Brurberg, M. B., Nielsen, B. J., Hansen, J. G., Yuen, J. (2008). Phenotypic variation in Nordic populations of Phytophthora infestans in 2003. Plant Pathol., 57, 227-234.

Malcolmson, J. F., Black, W. (1966). New $R$ genes in Solanum demissum Lindl. and their complementary races of Phytophthora infestans (Mont.) de Bary. Euphytica, 15, 199-203.

Malcolmson, J. F. (1969). Races of Phytophthora infestans occurring in Great Britain. Trans. Brit. Mycol. Soc., No. 3, 417-423.

Naess, S. K., Bradeen, J. M., Wielgus, S. M., Haberlach, G. T., McGrath, J. M. (2000). Resistance to late blight in Solanum bulbocastanum is mapped to chromosome 8. Theor. Appl. Genet., 101, 697-704.

Paterson, A. H., Tanksley, S. D., Sorrells, M. E. (1991). DNA markers in plant improvement. Adv. Agr., 46, 39-90.

Runno-Paurson, E., Fry, W. E., Myers, K. L., Koppel, M., Mand, M. (2009). Characterization of Phytophthora infestans isolates collected from potato in Estonia during 2002-2003. Eur. J. Plant Pathol., 124, 565-575.

Schwinn, F. J., Margot, P. (1991). Control with chemicals. In: Advances in Plant Pathology. Vol. 7: Phytophtora infestans, the cause of late blight of potato. Ingram, D. S., Williams, P. H. (eds.). Academic Press, London, pp. 193-224.

Skrabule, I., Zoteyeva, N., Mezaka, I., Vilcane, D., Usele, G. (2012). The adaptation of MAS for late blight resistance evaluation of potato breeding material. In: $13^{\text {th }}$ EuroBlight Workshop, $9^{\text {th }}-12^{\text {th }}$ October, St. Petersburg, pp. 179-186.

Stewart, H. E., Bradshaw, J. E., Pande, B. (2003). The effect of the presence of $R$-genes for resistance to late blight (Phytophthora infestans) of potato (Solanum tuberosum) on the underlying level of field resistance. Plant Pathol., 52, 193-198.

Umaerus, V., Umaerus, M. (1994). Inheritance of resistance to late blight. In: Potato Genetics. Bradshaw, J. E., Mackay, G. R. (eds.). CAB International, Wallingford UK, pp. 365-402.

Vossen, E. A. G. van der, Sikkema, G. J., Muskens, A., Wouters, M. Wolters, D., Pereira, P., Allefs, A. S. (2005). The Rpi-blb2 gene from Solanum bulbocastanum is an Mi-1 gene homolog conferring broad-spectrum late blight resistance in potato. Plant J., 44, 208-222.

Vleeshouwers, V. G., Rafaele, S., Vossen, J. H., Champouret, N., Oliva, R., Segretin, M. E., Rietman, H., Cano, L.M., Lokossou, A., Kessel, G., Pel, M. A., Kamoun, S. (2011). Understanding and exploiting late blight resistance in the age of effectors. Annu. Rev. Phytopathol., 49, 507-531.

Zoteyeva, N. M., Patrikeeva, M. V. (2010). Phenotypic characteristics of North-West Russian populations of Phytophthora infestans (2003-2008). In: Proceedings of the $12^{\text {th }}$ EuroBlight Workshop, 3th-6th May, Arras, pp. 213-216. 
Zoteyeva, N. M., Zimnoch-Guzowska, E. M. (2004). New method of evaluation for resistance to Phytophthora infestans in potato. Micologia $i$ fitopatologia [Зотеева Н. М., Зимнох-Гузовска Е. М. Новый метод оценки устойчивости клубней картофеля к фитофторозу. Микология и фитопатология], 38, 89-93 (in Russian).
Zoteyeva, N., Mežaka, I, Vilcāne, D., Carlson-Nilsson, U., Skrabule I., Rostoks N. (2014). Assessment of genes $R 1$ and $R 3$ conferring resistance to late blight and of gene Rysto conferring resistance to Potato virus $Y$ in two wild species accessions and their hybrid progenies. Proc. Latvian Acad. Sci. Section B, 68 (3/4), 133-141.

14 April 2015

\section{REZISTENCI NOTEICOŠO GĒNU $R 1$ UN R3A IETEKME UZ KARTUPEL̨U SELEKCIJAS KLONU BUMBULUU IZTURĪBU PRET LAKSTU PUVI}

Kartupeḷu selekcijas kloniem novērtēta bumbuḷu izturība pret lakstu puvi (izraisītājs Phytophthora infestans), izmantojot inokulācijas testu, kā arī noteikta gēnu $R l$ un $R 3$ a rezistenci noteicošo alēḷ klātbūtne, lietojot polimerāzes kēêdes reakcijas testu. Starp pārbaudītajiem kloniem tika identificēti paraugi ar augstu, vidēju un zemu izturības līmeni. Iepriekšējos pētījumos, kas veikti nelielam skaitam klonu, konstatēts, ka izturības līmeni būtiski ietekmējusi gēna $R 3 a$ izturību noteicošās alēles klātbūtne/iztrūkums, bet nebūtiska ietekme bija gēna $R 1$ izturību noteicošās alēles klātbūtnei. Veiktajā pētījumā datu statistiskā analīze neapstiprināja būtisku atšḳirīibu starp izturības līmeniem kloniem, kas satur gēnu $R l$ vai $R 3$ rezistenci noteicošās alēles. Bumbuḷu izturība kloniem, kas satur gēna $R 3 a$ rezistenci noteicošo alēli, bija ievērojami augstāka nekā kloniem, kas satur gēna $R l$ rezistenci noteicošo alēli vai nesatur nevienu no pārbaudīto gēnu rezistenci noteicošajām alēlēm. Atsevišḳos gadījumos kloniem, kuriem noteikta gēna $R 1$ izturību noteicošā alēle, bumbuḷu izturība bija augstāka, salīdzinot ar tā paša krustojuma izcelsmes kloniem, kuriem noteikta gēna $R 3 a$ rezistenci noteicošās alēles klātbūtne vai arī nav konstatēta neviena pārbaudītā gēna izturību noteicošā alēle. Kloni, kuros konstatēta abu pārbaudīto gēnu (Rl un $R 3 a)$ izturības noteicošo alēlu klātbūtne, uzrādīja augstu bumbuḷu izturības līmeni, tiem novēroja tikai nekrotisku reakciju uz bumbuḷu virsmas. 